\title{
Sustainable competitive advantage and green innovation: a review of joint scale propositions
}

\author{
Vantagem Competitiva Sustentável e Inovação Verde: Uma revisão \\ sobre proposições de escalas conjuntas.
}

\author{
Olívia Carolina de Resende Ribeiro ${ }^{1}$ (D), Pedro José Steiner Neto ${ }^{1}$ (D) \\ ${ }^{1}$ Universidade Positivo - UP, Programa de Mestrado e Doutorado em Administração, Curitiba, PR, Brasil. E-mail: \\ oliviacresende@gmail.com; pedrosteinerneto@gmail.com
}

How to cite: Ribeiro, O. C. R., \& Steiner Neto, P. J. (2021). Vantagem Competitiva Sustentável e Inovação Verde: Uma revisão sobre proposições de escalas conjuntas. Gestão \& Produção, 28(3), e5669,

https://doi.org/10.1590/1806-9649-2021v28e5669

\begin{abstract}
The objective of this work was to present the analysis instruments of Green Innovation that seek to relate it to Sustainable Competitive Advantage. Determining the research instruments through which we can analyze the relations between Organizational Capacity, Green Innovation, and Performance can enlighten us in what contributes with the levels of competitiveness of a specific industry, i.e., the sustainable competitive advantage. To do this, we focused on articles indexed in Thomson Reuters, 'Web of Science databank. We analyzed the articles have been most cited and which had presented scales for the analysis and understanding of Green Innovation instruments. We explored three of the most cited articles. These works address innovation from the perspective of Green Innovation and seek to analyze the superior performance of environmental innovations through specific scales. The studies in question adopt quantitative research approaches and operationalized through surveys. According to our analysis, the instruments can represent significant advances concerning the problem addressed in this study.
\end{abstract}

Keywords: Green Innovation; Green Innovation Performance; Capabilities; Competitiveness; Sustainable Competitive Advantage.

Resumo: O objetivo deste trabalho foi apresentar os instrumentos de análise de Inovação Verde que buscam relacioná-la à Vantagem Competitiva Sustentável; determinar instrumentos de pesquisa, por meio dos quais possam ser analisadas as relações entre Capacidades, Inovações Verdes e o Desempenho das organizações; colaborar no entendimento do que venha contribuir com os níveis de competitividade de determinada indústria, ou seja, a vantagem competitiva sustentável. Para tanto, a atenção foi direcionada aos artigos indexados no banco de dados da Web of Science, da Thomson Reuters. Foram analisados os mais citados e que haviam escalas para a análise e compreensão dos instrumentos de Inovação Verde. Dos trabalhos analisados, três deles se destacam, pois apreendem a inovação sob a perspectiva da Inovação Verde e, por meio de escalas específicas, procuram analisar o desempenho superior de inovações ambientais. Os estudos em questão adotam abordagens quantitativas de pesquisa e foram operacionalizados por meio de surveys. De acordo com a análise, os instrumentos podem ser considerados como avanços significativos no que se refere à problemática deste estudo.

Palavras-chave: Inovação Verde; Desempenho de Inovação Verde; Capacidades; Competitividade; Vantagem Competitiva Sustentável.

Recebido em June 19, 2019 - Aceito em Nov 11, 2019

Financial support: None. 


\section{Introduction}

Sustainable competitive advantage is the heart of strategy research, and "innovation is one of the main factors that positively influence competitiveness and economic development" (Pinsky et al., 2015, p.226).

One can undertand, then, what sustainable competitive advantage is achieved, when the company is successful, in the implementation of a strategy, that adds superior value to the consumer and that competitors cannot reproduce or believe that it is costly to imitate it (Hitt et al., 2002; Ireland et al., 2014). In this way, sustainable competitive advantage occurs, as the organization brings greater economic value, compared to other companies in the same sector, thus, achieving superior market performance. The company, when obtains the superior performance, allows the creation of differentiated value from the other competitors, being able, therefore, to connect this result, to the differentiation strategy of this company, in relation to the other agents of a determined market segment and to catch up superior results in parallel with the industry behavior. (Wernerfelt, 1984; Porter, 1996; Barney, 1991; Barney \& Hesterly, 2011).

In order to ensure sustainable competitive advantage, the company must renew continually itself, with the intent of better attending the environmental demands and its internal needs. Individuals inserted in this context must think strategically and act in an entrepreneurial way, in such a manner, they can exercise their activities with superior performance (Teece, 2009), as well as possess the ability to act intentionally to create new knowledge (Pandza \& Thorpe, 2009; Adner \& Helfat, 2003), processes, products and services.

For the Manual de Oslo (2018), management capacity is a factor that can influence the company's ability to engage in "innovation activities introduce innovations and generate innovation results". Although studies have identified several management practices and resources, which have related to the performance of innovation, Manual de Oslo (2018) highlights two main areas: "the competitive strategy of a company and the organizational and managerial capacities used to implement this strategy" (Manual de Oslo, 2018, p. 106).

As a result, the understanding of this phenomenon by researchers, executives and economists indicates that innovation is the vital point, for the maintenance and / or creation of social welfare standards, in addition to standing out as the source of competitive advantages, either at the organizational level or in terms of national differentiation (Miller \& Morris, 1999).

In this context of seeking for Sustainable Competitive Advantage, appearing the first signs of change moviments in favor of Sustainable Development, which it has perceived as the fruits of indignation with social inequalities and environmental degradation, due to market failures. Understanding of the subject by these movements is there is no possibility to maintain the same levels of pattern, both production and consumption, as, in addition to the exacerbated social inequalities (in which many have access to little and few have access to much), the planet's natural resources are finite.

Thus, thinking about innovation is likely to compromise organizational sustainability itself, without considering sustainability. A sustainable organization, according to Barbieri et al. (2010), must attend, at the same time, the economic terms, in the generation of income; the social issues, in promoting inclusion; protection of minorities and vulnerable groups; the balance between genders, among others; to the environmental, respecting the ability to support the environment (Barbieri et al., 2010).

Due to the important theme, exhaustively, it has been debating about instruments that enable the assessment of the innovation performance of companies and countries 
(Manual de Oslo, 2018, 2005, 1997; Nascimento, 2015; Nascimento et al., 2013). However, what is happening, especially in Brazil, is that, beyond the studies consider macroeconomic indicators; few consider green innovation and companies' competitive advantage. The studies by Conto et al. (2016) and Torres et al. (2017) deal with innovation and competitive advantage, but do not analyze green innovation. The work of Arenhardt et al. (2012) was one of the few studies in Brazil that analyzes the influence of adopting green innovations, in obtaining competitive advantage in companies. The authors analyzed the Brazilian electrical and electronic sectors, endowing themselves with the conceptual model proposed by Chen et al. (2006), and the direction of the studies, in a world increasingly focused on environmental issues, becomes poignant to the evaluate the instruments that make the relations.

Based on the problematic presented and to pursue innovation metrics, which attend the environmental requirements and the rise of discussions about green innovation in the world, this study aims to analyze, from a perspective of comparison, the main green innovation scales that relate to sustainable competitive advantage. Therefore, three studies has been analyzing, that were concerned with unraveling the relations. The studies have been developing, hing on the work of Chen et al. (2006) and gaining new outlines and improvements. The research instruments used and the main relations found have considered, addressing the most relevant contributions of each work.

The source of data, from scientific articles, was the indexed articles, in the Thomson Reuters Web of Science database, which were the most had cited. This database was used as a basis for searching for articles associated with the theoretical field, due to its relevance attributed by the academic community, mainly because it gives access to more than 12,000 scientific journals and more than 1 billion cited references (King, 2016).

\section{Sustainable competitive advantage and green innovation}

Since the industrial revolution, industrial activities have generated immeasurable environmental impacts, making this a global problem that grows every day in our planet. Over the past few decades, some corrective policies have been designing and implementing, in order to redress the environmental damage caused by industries, population growth and consumption habits. To protect the planet Earth, it is necessary to adopt approaches that prevent environmental degradation, ensuring that future generations are able to survive on the planet.

Thenceforth, some concepts had been creating; in attampt to reduce, the impact of industrial activities, by that time, seemed as the main cause of environmental degradation. Concepts such as green management, green marketing, green production, green innovation, among others. According to Chen et al. (2006), the elevation of international environmental rules, such as, for example, the Montreal Convention, the Kyoto Protocol, among others, beyond the popular environmental awareness of consumers, brought significant impacts to companies around the world.

In the past, the vast majority of managers believed that investing in environmental protection practices, rather than bringing benefits to the company, was harmful to the business, and environmental investments were minimal, only represented by those to whom the company has driven by law or as a corporate social responsibility practice (Chen et al., 2006). Under strict international standards and conventions, turned at protecting life and the rise of a more conscious consumer, companies were required to adopt a new posture. This new demand enabled environmental protection practices to be included in the organizations' management agenda, which includes green innovation as 
an attribute that guarantees competitive advantage, especially in highly polluting industries.

According to Porter \& Van der linde (1995), innovation is one of the forces that make it possible to raise the corporate competitive advantage. Thus, under increasingly stringent environmental regulations, it is essential to consider the product's life cycle, when decisions involve design, product and process. Green products and processes not only reduce the negative impact on the environment, but can also increase the company's competitive advantage (Porter \& Van Der Linde, 1995; Klassen \& Whybark, 1999; Rao, 2002; Rao \& Holt, 2005; Chen et al., 2006; Chen, 2008; Chiou et al., 2011). Some papers, such as Chen et al. (2006), Chen (2008) and Chiou et al. (2011), directed their efforts in order to elucidate the positive effect of green innovation in competitive advantage.

New techniques, practices, systems and products to avoid or reduce environmental damage has been defining as Green innovations (Kemp \& Arundel, 1998; Beise \& Rennings, 2005; Marchi, 2012). This meaning apprehends changes, in the product portfolio or in the production processes that attend sustainability goals, such as waste management, eco-efficiency, emissions reduction, recycling, ecological design or any other action implemented by companies to reduce their environmental impact. It is worth remembering that this definition had based on the effect of innovation activities, regardless of the initial intention and includes incremental and radical improvements (Marchi, 2012).

Green innovation had classified into three main categories: green product innovation; green process innovation (Klassen \& Whybark, 1999; Porter \& Van der Linde, 1995; Hart, 1995; Schmidheiny \& Timberlake, 1992; Chen et al., 2006; Chen, 2008; Chiou et al., 2011); and green managerial innovation (Chiou et al., 2011).

Studies like Chen et al. (2006) found that innovations in green products and green manufacturing processes are positively associated with corporate competitive advantage. Based on this result, Chen (2008) improved his studies and then introduced the concept of essential competences. His study showed, on the one hand, that green core competencies, defined as "collective learning and skills in green innovation and environmental management", positively influence a company's ability to develop green product and process innovations (Chen, 2008, p. 533). On the other hand, it helps to improve a company's green image and therefore its competitive advantage.

In his project, Chiou et al. (2011) considered the impact of green innovation, in particular, on environmental performance throughout the supply chain. For Chiou et al. (2011), a potential benefit of green innovation is that it increases the entry barriers of other competitors. In addition, the reduction of pollution and hazardous toxic waste can contribute to ecological efficiency, as well as reducing the cost of eliminating hazardous waste, improving regulatory compliance and responding to external environmental pressures from customers, as well as enabling a product better suited to the pressures of society, thus guaranteeing an improvement in global competitive advantage. Therefore, "organizations must implement environmental management and integrate green innovation in business strategies, in order to build and maintain competitive advantage" (Chiou et al., 2011, p.833).

According to Lichtenthaler (2009), in contexts characterized by high market uncertainties and technological turbulence, the absorption capacity on innovation performance is greater, because internal prior knowledge becomes even more important for the successful development of innovations. Marchi (2012) states that the complexity and systematics of environmental innovations and the technological and market uncertainties that characterize many green technologies suggest that they represent such a context (Marchi, 2012, p. 616). The mode that companies integrate environmental concerns in their strategies, while consolidating their competitive advantage, occurs 
through environmental innovations. Although, the interest in environmental innovations is incresing, research on this field is still limited.

\section{Research methodology}

The present study has characterized as a systematic review of green innovation assessment metrics, with the aim of analyzing the main metrics that examine green innovation from the perspective of competitive advantage. In studies that involve systematic review, some limitations that it has identified with regard to research, which are errors in the demarcation of search terms, data collection and general perception of the field (Bittar et al., 2011). Keeping these limitations in mind and seeking to reduce bias, the research organization framework was adopted and adapted (Table 1), elaborated by Prado et al. (2016).

Table 1. Framework Research organization.

\begin{tabular}{|c|c|c|c|}
\hline \multicolumn{2}{|c|}{ Stage } & Procedure & Description \\
\hline \multirow{10}{*}{ Database } & (1) & 1.1 & Choice of scientific basis or journals \\
\hline & Field of study & 1.2 & Delimitation of terms representing the field \\
\hline & & 1.3 & Delimitation of other terms to determine results \\
\hline & (2) & 2.1 & Download references - EndNote software \\
\hline & \multirow{3}{*}{$\begin{array}{l}\text { Selection } \\
\text { procedures } \\
\text { (database) }\end{array}$} & 2.2 & Download references in spreadsheet format \\
\hline & & 2.3 & Organization of references in EndNote \\
\hline & & 2.4 & $\begin{array}{c}\text { Organization of analysis matrix in electronic } \\
\text { spreadsheet }\end{array}$ \\
\hline & (3) & 3.1 & Elimination of articles through floating reading \\
\hline & \multirow{2}{*}{$\begin{array}{c}\text { Adequacy and } \\
\text { organization of } \\
\text { data }\end{array}$} & 3.2 & Elimination through polysemy analysis of terms \\
\hline & & 3.3 & Search for complete articles in PDF \\
\hline \multirow{5}{*}{$\begin{array}{l}\text { Analysis and } \\
\text { interpretation }\end{array}$} & (4) & 4.1 & Analysis of research instruments \\
\hline & \multirow{4}{*}{$\begin{array}{l}\text { Scientific } \\
\text { production } \\
\text { analysis }\end{array}$} & 4.2 & Scales analysis \\
\hline & & 4.3 & Analysis of concepts \\
\hline & & 4.4 & Analysis of methodological elements \\
\hline & & 4.5 & $\begin{array}{l}\text { Analysis of the relations between research } \\
\text { instruments }\end{array}$ \\
\hline
\end{tabular}

Source: Adapted from Prado et al. (2016).

In view of looking for minimizing errors, the study feeds back, in other words, the steps are not exactly sequential.

\subsection{Operationalization of the database}

Following the presented framework analysis, the first stage concerns the (1) field under study. Then select, choose to perform a search, based on data from the Thomson Reuters - Web of Science (procedure 1.1). The delimitation of a single base must create two factors; a) standardization of academic publications (enabling comparative analysis) and; b) mainly due to the priority of this base (Pinto et al., 2014; Liu et al., 2014; Prado et al., 2016). Right after, in procedures (1.2) and (1.3), we sought to identify the terms that could represent this field of study (field labels) and the other terms. Based on the project of 
Pinsky et al. (2015), for green innovation, the labels "green innovation"," "sustainable innovation"," "eco-innovation", "environmental innovation". Here, it is worth to highlight the search for the field of study in the Web Of Science followed as shown in Table 2.

Table 2. Summary of research requirements.

\begin{tabular}{cc}
\hline Search systematization & Filters \\
\hline (a) Search field & $\begin{array}{c}\text { Title: (green innovation) OR Title: (sustainable } \\
\text { innovation) OR Title: (eco-innovation) OR Title: } \\
\text { (environmental innovation) }\end{array}$ \\
\hline (b) Document types & Articles \\
\hline (c) Web of Science categories & All categories \\
\hline (d) Allotted time & From the beginning \\
\hline (f) Research date & March 20, 2018 \\
\hline
\end{tabular}

Source: Elaborated by the authors.

Therefore, we have followed step (2) (Table 1) which refers to the database selection procedures. First, the references (2.1) had been downloading to be managing in the EndNote software. Then, the references had been downloading in an electronic spreadsheet format (2.2). After these procedures, the references has been organizing in EndNote (2.3) and arranging in the analysis matrix in an electronic spreadsheet (2.4). Throughout this process, data have been organizing and systematizing.

The next step was the adaptation and organization of the data to step (3), the search with more than one term and the link with the competitive advantage; initially, it is exposed the difficulty in considering that all articles establish some relation with the intended analysis. After the elimination of articles, through floating reading and analysis of the polysemy of the terms, at the end of the filtering, 50 articles were selected that dealt with the relationship between green innovation and competitive advantage. Of the 50 articles, 20 had been more citing and three presented the established relations and worked with quantitative analysis, presenting instruments that could have been analyzing.

\subsection{Analysis and interpretation}

For analysis and interpretation of the results, the three had most cited articles have been analyzing and the characteristics of the research instruments dealing with the relations, scales, concepts, methodological aspects and the relations between the research instruments presented in each paper, compiling the information. In each case, we sought to synthesize the results descriptively and present the observed relationships.

Thus, in the next topic, the metrics developed that relate green innovation and companies' competitive advantage will have been presenting, so that they can be analyzing.

\footnotetext{
1 Green Innovation, in Portuguese, "Inovação Verde", has related to studies that direct their efforts towards the performance of innovation, considering the positioning of the company and the green image it generates, it does not deepen in the analysis of the life cycle (Pinsky et al., 2015).

2 Sustainable Innovation, in Portuguese, "Inovação Sustentável", focuses on approaches to technological niches; considers technological and social changes concomitantly (Pinsky et al., 2015).

${ }^{3}$ Eco-innovation, in Portuguese, "Ecoinovação", considers the impact and assessment of the life cycle; technological, social and institutional innovation; prioritizes environmental performance over the environmental goal (Pinsky et al., 2015).

${ }^{4}$ Environmental Innovation, in Portuguese, "Inovação Ambiental", oriented predominantly by environmental regulation; aims at cost reduction; does not delve into the life cycle analysis (Pinsky et al., 2015).
} 


\section{Green innovation scale}

Determining research instruments, through which the relations between green innovations and the performance of organizations has been analyzing, can collaborate in understanding of what will contribute to the levels of competitiveness of a given industry, that is, the sustainable competitive advantage. Mainly, in a scenario of policies aimed at environmental protection, both for companies and for governments and a growing consumer demand for companies to be more sustainable.

It is understood, an among of factors that guide the use of green innovations, to explain organizational phenomena, the emerging demand stands out both by consumers and by environmental regulations and laws that must be adopted by companies, as well as by the capacity of the company. Thematic interweave with various administrative theories. Among these theories, we can identify RBV, Dynamic Capabilities and innovation, as highlighted in the work of Chen et al. (2006), Chen (2008) and Chiou et al. (2011).

The ability to interweave with different theoretical currents allows a better understanding of the phenomenon, once, the most diverse relations have identified, and it becomes feasible to establish theoretical constructions that investigate various elements that converge at the same point - sustainable competitive advantage.

Innovation is a theme that captures the search for metrics, and the emergence of discussions about green innovation, mainly, due the lack of standard on the key term. Therefore, it demands greater attention and, as a result of these facts, the following is a comparison of the scales found that use the relationship between green innovation and sustainable competitive advantage, in which Chen et al. (2006), Chen et al. (2008) and Chiou et al. (2011).

\subsection{Chen's research instrument et al., (2006)}

The central justification of Chen et al. (2006) is the perception that, at the time, studies of the relation between impacts of environmental protection on corporate advantage had not received much attention from the academic community. There were no studies focusing on the influence of green product innovation and green process innovation performance on corporate competitive advantage.

The project in evidence provides the green innovation activities that a company carries out in terms of green product and process innovation are related to green products or processes that include innovation in technologies that guarantee energy savings, prevention of pollution, waste recycling, green product projects or corporate environmental management. Green innovation has used to improve the performance of environmental management in order to satisfy the requirement for environmental protection (Lai et al., 2003). Analyzing the differences in the performance of green product and process innovation in different industries.

Therefore, it is important to highlight that the article tests hypotheses of innovation of green products and innovation of green process. In relation to the corporate competitive advantage, in a conjuncture of technological innovation, without giving importance to the aspects related to the changes, in organizational structure and administrative processes, as well as, not taking into account the social issues involved in the concept of development. Thus, the project has been directing to the analysis of how the studied companies transform product innovation and green process into performance.

To construction of definitions about the performance of product innovation and green process, the ISO 14031 standard had used. This standard defines performance of green product innovation as the performance, in product innovation, which is related to 
environmental innovation, and the performance of green process innovation as performance in process innovation that is related to energy saving, pollution prevention, waste recycling or absence of toxicity (Lai et al., 2003). To define corporate competitive advantage, the authors resorted to Barney (1991), Coyne (1986) and Porter (1985) and, according them the "corporate competitive advantage" is that, in which the company occupies some positions, whose competitors they cannot copy their strategy, and the company can derive the sustainable benefits of this successful strategy (Barney, 1991; Coyne, 1986; Porter, 1985).

The authors developed a bidirectional scale (Chart 1); it understands green product innovations and green process innovations, as two distinct dimensions. Each dimensions is composed of four indicators, on a five-point 'likert' scale, which seeks to understand whether the performance of green innovation has had a positive effect on competitive advantage.

Chart 1. Research instrument by Chen et al. (2006).

\begin{tabular}{|c|c|c|c|c|c|c|}
\hline \multirow{3}{*}{\multicolumn{2}{|c|}{$\begin{array}{c}\text { To explore whether the performance of green } \\
\text { innovation has had a positive effect on } \\
\text { competitive advantage. }\end{array}$}} & \multicolumn{5}{|c|}{ Degree of relevance } \\
\hline & & \multicolumn{5}{|c|}{1 (strongly disagree) to 5 (strongly agree) } \\
\hline & & 1 & 2 & 3 & 4 & 5 \\
\hline \multirow{4}{*}{$\begin{array}{l}\text { Green Product } \\
\text { Innovation } \\
\text { Performance }\end{array}$} & $\begin{array}{l}\text { The company defines the } \\
\text { raw materials and inputs in } \\
\text { the development or design } \\
\text { of the product, which } \\
\text { generates less pollution. }\end{array}$ & & & & & \\
\hline & $\begin{array}{l}\text { The company defines the } \\
\text { raw materials and inputs in } \\
\text { the development or project } \\
\text { of the product that } \\
\text { consumes the least amount } \\
\text { of energy and resources. }\end{array}$ & & & & & \\
\hline & $\begin{array}{l}\text { The company uses the } \\
\text { least amount of materials } \\
\text { to compose the product } \\
\text { in order to conduct the } \\
\text { development or design of } \\
\text { the product. }\end{array}$ & & & & & \\
\hline & $\begin{array}{l}\text { It is prudent for the } \\
\text { company to start a product } \\
\text { development project if it will } \\
\text { be easy to recycle, reuse } \\
\text { and decompose. }\end{array}$ & & & & & \\
\hline \multirow{4}{*}{$\begin{array}{l}\text { Green Process } \\
\text { Innovation } \\
\text { Performance }\end{array}$} & $\begin{array}{l}\text { The company's } \\
\text { manufacturing process } \\
\text { effectively reduces the } \\
\text { emission of hazardous } \\
\text { substances or waste. }\end{array}$ & & & & & \\
\hline & $\begin{array}{l}\text { The company's } \\
\text { manufacturing process } \\
\text { recycles waste and } \\
\text { emissions that allows be } \\
\text { treating and reusing. }\end{array}$ & & & & & \\
\hline & $\begin{array}{l}\text { The company's } \\
\text { manufacturing process } \\
\text { reduces the consumption of } \\
\text { water, electricity, coal or oil. }\end{array}$ & & & & & \\
\hline & $\begin{array}{l}\text { The company's } \\
\text { manufacturing process } \\
\text { reduces the use of raw } \\
\text { materials. }\end{array}$ & & & & & \\
\hline
\end{tabular}


Chart 1. Continued...

\begin{tabular}{|c|c|c|c|c|c|c|}
\hline \multirow{3}{*}{\multicolumn{2}{|c|}{$\begin{array}{c}\text { To explore whether the performance of green } \\
\text { innovation has had a positive effect on } \\
\text { competitive advantage. }\end{array}$}} & \multicolumn{5}{|c|}{ Degree of relevance } \\
\hline & & \multicolumn{5}{|c|}{1 (strongly disagree) to 5 (strongly agree) } \\
\hline & & 1 & 2 & 3 & 4 & 5 \\
\hline \multirow{8}{*}{$\begin{array}{l}\text { Corporate } \\
\text { Competitive } \\
\text { Advantage }\end{array}$} & $\begin{array}{l}\text { The company has the } \\
\text { competitive advantage of } \\
\text { low cost compared to } \\
\text { other competitors. }\end{array}$ & & & & & \\
\hline & $\begin{array}{l}\text { Quality of the products or } \\
\text { services offered by the } \\
\text { company is better than } \\
\text { other competitors' } \\
\text { products or services. }\end{array}$ & & & & & \\
\hline & $\begin{array}{l}\text { The company is more } \\
\text { capable of R\&D and } \\
\text { innovation than its } \\
\text { competitors are. }\end{array}$ & & & & & \\
\hline & $\begin{array}{l}\text { The company has better } \\
\text { management skills than } \\
\text { its competitors have. }\end{array}$ & & & & & \\
\hline & $\begin{array}{l}\text { The company's } \\
\text { profitability is better. }\end{array}$ & & & & & \\
\hline & $\begin{array}{l}\text { The company's growth } \\
\text { exceeds that of its } \\
\text { competitors. }\end{array}$ & & & & & \\
\hline & $\begin{array}{c}\text { The company is a } \\
\text { pioneer in some } \\
\text { important fields and } \\
\text { occupies an important } \\
\text { position. }\end{array}$ & & & & & \\
\hline & $\begin{array}{l}\text { The company's corporate } \\
\text { image is better than the } \\
\text { other competitors are. }\end{array}$ & & & & & \\
\hline
\end{tabular}

Source: Elaborated based on Chen et al. (2006).

The authors concluded that the results show that the innovation performance of green products and green processes was positively associated with corporate competitive advantage. Therefore, investment in the innovation of green products and green processes was useful for the companies studied. In other words, the greater is the investment in the innovation of green products and green processes, the greater is the corporate competitive advantage.

\subsection{Chen's research instruments (2008)}

Chen (2008) focused on finding the right view and assessment for new concepts of environmental management, in line with environmental trends. In order to help companies improve their essential skills in green innovation and increase their green images. For such, the study proposed a new construct, supported by the concept of central competence, defined by Prahalad \& Hamel (1990), called green central competence.

Based on the author's idea, a central green competence deals with collective learning and learning about green innovation and environmental management in an organization. The central argument is that an environmental company is responsible for its core competencies and environmentally friendly products (the tangible results of green core competencies). In addition, the central green competence proposed in the study, meets three requirements: i. provides potential access to meet a wide range of environmental needs in markets; ii. Contributes to customer benefits and; iii. Imitation by competitors is difficult (Prahalad \& Hamel, 1990). 
To validate the construct, an empirical study had carried out in order to verify the research hypotheses and explore the managerial implications of the companies' green core competencies. Two other builders had been created in the project, to assess and discuss how the relations between central green competence, the performance of green innovation and the green image (Chart 2). The study sought to fill this research gap and highlighted that green core competence had a positive effect on the performance of green innovation and referred to Chen et al. (2006), to divide the performance of green innovation into the performance of product innovation green and green process innovation performance.

To constitutive definition of the constructs of "green product innovation performance" and "green process innovation performance", the author turned to Chen et al. (2006). To definition of "green product innovation performance", Chen et al. (2006) state it is product innovation performance that is related to environmental innovation, including product innovation that is involved, in energy savings, prevention of pollution, waste, recycling projects, without toxicity or green products. As for "performance of innovation in green process", Chen et al. (2006) states that it is performance in process innovation that is related to energy saving, pollution prevention, waste recycling or toxicity (Chen et al., 2006; Chen, 2008).

To definition of the "green image" constructs, the works of Weiss et al. (1999) and Keller \& Aaker (1992) had been using. Referring to Weiss et al. (1999), the study measured "green reputation" for items considered "professionals", "successful", "well established" and "stable". And Keller \& Aaker (1992), to measure "green credibility", which covered the items "reliability", "dependency capacity" and "concern for customers" (Chen, 2008).

Chart 2. Chen's research instrument (2008).

\begin{tabular}{|c|c|c|c|c|c|c|c|c|}
\hline \multirow{3}{*}{\multicolumn{2}{|c|}{$\begin{array}{l}\text { Relations between Green Competence, Green } \\
\text { Innovation Performance and Green Image }\end{array}$}} & \multicolumn{7}{|c|}{ Degree of relevance } \\
\hline & & \multicolumn{7}{|c|}{1 (strongly disagree) to 7 (strongly agree) } \\
\hline & & 1 & 2 & 3 & 4 & 5 & 6 & 7 \\
\hline \multirow{5}{*}{$\begin{array}{l}\text { Green Central } \\
\text { Competence }\end{array}$} & $\begin{array}{l}\text { The company's environmental } \\
\text { capabilities, technologies or 'know-how' } \\
\text { are rare in the market. }\end{array}$ & & & & & & & \\
\hline & $\begin{array}{l}\text { The company's environmental } \\
\text { capabilities, technologies or 'know-how' } \\
\text { are less imitated by competitors. }\end{array}$ & & & & & & & \\
\hline & $\begin{array}{c}\text { The company's environmental } \\
\text { capabilities, technologies or 'know-how' } \\
\text { are difficult to replace. }\end{array}$ & & & & & & & \\
\hline & $\begin{array}{l}\text { The company's environmental capabilities, } \\
\text { technologies or 'know-how' offer potential } \\
\text { access to meet a large variety of } \\
\text { environmental needs in the market. }\end{array}$ & & & & & & & \\
\hline & $\begin{array}{l}\text { The company's environmental } \\
\text { capabilities, technologies or 'know-how' } \\
\text { contribute to customer benefits } \\
\text { (Prahalad \& Hamel, 1990). }\end{array}$ & & & & & & & \\
\hline \multirow{4}{*}{$\begin{array}{l}\text { Green Product } \\
\text { Innovation } \\
\text { Performance }\end{array}$} & $\begin{array}{l}\text { The company defines the raw materials } \\
\text { and inputs in product development or } \\
\text { design that generate less pollution. }\end{array}$ & & & & & & & \\
\hline & $\begin{array}{l}\text { The company defines the raw materials } \\
\text { and inputs in the development or project } \\
\text { of the product that consumes the least } \\
\text { amount of energy and resources. }\end{array}$ & & & & & & & \\
\hline & $\begin{array}{l}\text { The company uses the least amount of } \\
\text { materials to compose the product, to } \\
\text { conduct product development or design. }\end{array}$ & & & & & & & \\
\hline & $\begin{array}{c}\text { It is prudent for the company to start a } \\
\text { product development project if it is easy } \\
\text { to recycle, reuse and decompose. } \\
\text { (Chen et al., 2006). }\end{array}$ & & & & & & & \\
\hline
\end{tabular}


Chart 2. Continued...

\begin{tabular}{|c|c|c|c|c|c|c|c|c|}
\hline \multirow{2}{*}{\multicolumn{2}{|c|}{$\begin{array}{l}\text { Relations between Green Competence, Green } \\
\text { Innovation Performance and Green Image }\end{array}$}} & \multicolumn{7}{|c|}{ Degree of relevance } \\
\hline & & \multicolumn{7}{|c|}{1 (strongly disagree) to 7 (strongly agree) } \\
\hline & & 1 & 2 & 3 & 4 & 5 & 6 & 7 \\
\hline \multirow{4}{*}{$\begin{array}{l}\text { Green Process } \\
\text { Innovation } \\
\text { Performance }\end{array}$} & $\begin{array}{l}\text { The company's manufacturing process } \\
\text { effectively reduces the emission of } \\
\text { hazardous substances or waste. }\end{array}$ & & & & & & & \\
\hline & $\begin{array}{l}\text { The company's manufacturing process } \\
\text { recycles waste and emissions that } \\
\text { allows them to be treating and reusing. }\end{array}$ & & & & & & & \\
\hline & $\begin{array}{l}\text { The company's manufacturing process } \\
\text { reduces the consumption of water, } \\
\text { electricity, coal or oil. }\end{array}$ & & & & & & & \\
\hline & $\begin{array}{l}\text { The company's manufacturing process } \\
\text { reduces the use of raw materials } \\
\text { (Chen et al., 2006). }\end{array}$ & & & & & & & \\
\hline \multirow{8}{*}{ Green Image } & $\begin{array}{l}\text { The company is considering the best } \\
\text { reference in environmental } \\
\text { management. }\end{array}$ & & & & & & & \\
\hline & $\begin{array}{l}\text { The company is professional in relation } \\
\text { to environmental management. }\end{array}$ & & & & & & & \\
\hline & $\begin{array}{l}\text { The company is well-succeed in } \\
\text { environmental management. }\end{array}$ & & & & & & & \\
\hline & $\begin{array}{l}\text { The company is well involved in } \\
\text { environmental management. }\end{array}$ & & & & & & & \\
\hline & $\begin{array}{l}\text { The company's reputation for } \\
\text { environmental management is stable. }\end{array}$ & & & & & & & \\
\hline & $\begin{array}{l}\text { The company is reliable in relation to } \\
\text { environmental management. }\end{array}$ & & & & & & & \\
\hline & $\begin{array}{l}\text { The company is reliable in relation to } \\
\text { environmental management. }\end{array}$ & & & & & & & \\
\hline & $\begin{array}{l}\text { The company is concerned with customers } \\
\text { in relation to environmental management } \\
\text { (Keller \& Aaker, 1992; Weiss et al., 1999). }\end{array}$ & & & & & & & \\
\hline
\end{tabular}

Source: Elaborated based on Chen (2008).

The empirical results of this study showed that the green core competencies of companies had positive effects, on the innovation performance of green products, the innovation performance of green processes and green images. Therefore, investment in green core competence, in the performance of green product innovation and in the performance of green process innovation was useful for companies. In addition, this research also found that green product innovation and green process innovation had partial mediation effects between green core competencies and companies' green images (Chen, 2008).

\subsection{Research instrument by Chiou et al. (2011)}

The project of Chiou et al. (2011) also looks for the relations between green innovation and competitive advantage, however, unlike the previous ones; it seeks to elucidate, in a broader way, the relationship between the adoption of environmental practices, throughout the chain supply, green innovation, environmental performance and competitive advantage. The authors also estimate the understanding that the demand for green innovation comes from two sources. The first one comes from the environmental awareness of consumers who demand, more and more "green" products, followed by compliance with regulations and legislation and cost savings.

Based on the authors' ideas, continuous innovation is a vital solution, to overcome the pressures of customers, competitors and regulators (Porter \& Van Der Linde, 1995; Chiou et al., 2011). Therefore, it is very important to adopt green innovation and 
implement Green Supply Chain Management (GSCM) practices within an organization's value chain (Steger, 1993; Chiou et al., 2011).

About the classification of green innovation, the authors supported themselves based on the project of Chen et al. (2006) and Chen, 2008. Green innovation has been classifing, for the authors, into three main categories: innovation of green products; green process innovation; and green managerial innovation (Chen et al., 2006; Chen, 2008; Chiou et al., 2011). Chen et al. (2006) concluded, "innovations in green products and green manufacturing processes are positively associated with corporate competitive advantage" (Chiou et al., 2011, p.823). Chen (2008) showed that green core competencies, defined as collective learning and capacities for green innovation and environmental management, "positively influence a company's ability to develop green product and process innovations" (Chiou et al., 2011, p.823) and through the company's positive green image it generates competitive advantage.

The study sought to answer two research questions: what extent are companies making the supply chain greener and implementing green innovation? Are there direct and indirect significant links between the greenest supplier, green innovation, environmental performance and competitive advantage? (Chiou et al., 2011). To answer these questions, the authors developed six constructs (Chart 3), with their respective indicators, which were measured using a five-point Likert scale $(1=$ strongly disagree and $5=$ strongly agree $)$.

Chart 3. Research instrument by Chiou et al. (2011).

\begin{tabular}{|c|c|c|c|c|c|c|}
\hline \multirow{3}{*}{\multicolumn{2}{|c|}{$\begin{array}{l}\text { The influence of greening suppliers and green } \\
\text { innovation on environmental performance and } \\
\text { competitiveness }\end{array}$}} & \multicolumn{5}{|c|}{ Degree of relevance } \\
\hline & & \multicolumn{5}{|c|}{1 (strongly disagree) to 5 (strongly agree) } \\
\hline & & 1 & 2 & 3 & 4 & 5 \\
\hline \multirow{6}{*}{ Greening the supplier } & $\begin{array}{l}\text { Selection of suppliers by } \\
\text { environmental criteria. }\end{array}$ & & & & & \\
\hline & $\begin{array}{c}\text { Require and assist suppliers to } \\
\text { obtain third party certification of } \\
\text { the environmental } \\
\text { management system. }\end{array}$ & & & & & \\
\hline & $\begin{array}{l}\text { Provide environmental } \\
\text { awareness seminars and } \\
\text { training for suppliers. }\end{array}$ & & & & & \\
\hline & $\begin{array}{c}\text { Provide technical } \\
\text { environmental advice to } \\
\text { suppliers and contractors in } \\
\text { order to help suppliers meet } \\
\text { environmental criteria. }\end{array}$ & & & & & \\
\hline & $\begin{array}{c}\text { Invite suppliers to participate } \\
\text { in the development and } \\
\text { design stage. }\end{array}$ & & & & & \\
\hline & $\begin{array}{l}\text { Sending an internal auditor to } \\
\text { assess the supplier's } \\
\text { environmental performance. }\end{array}$ & & & & & \\
\hline \multirow{3}{*}{$\begin{array}{l}\text { Green product } \\
\text { innovation }\end{array}$} & $\begin{array}{l}\text { Use less polluting / toxic } \\
\text { materials. (Use ecological } \\
\text { material). }\end{array}$ & & & & & \\
\hline & $\begin{array}{l}\text { Improve and design } \\
\text { environmentally friendly } \\
\text { packaging (example: use } \\
\text { less paper and plastic) for } \\
\text { existing and new products. }\end{array}$ & & & & & \\
\hline & $\begin{array}{l}\text { Recover products, at the } \\
\text { end of the company's life, } \\
\text { adopting recycling. } \\
\text { Use eco-labeling. }\end{array}$ & & & & & \\
\hline
\end{tabular}


Chart 3. Continued...

\begin{tabular}{|c|c|c|c|c|c|c|}
\hline \multirow{3}{*}{\multicolumn{2}{|c|}{$\begin{array}{l}\text { The influence of greening suppliers and green } \\
\text { innovation on environmental performance and } \\
\text { competitiveness }\end{array}$}} & \multirow{2}{*}{\multicolumn{5}{|c|}{$\begin{array}{c}\text { Degree of relevance } \\
1 \text { (strongly disagree) to } 5 \text { (strongly agree) }\end{array}$}} \\
\hline & & & & & & \\
\hline & & \multirow[t]{2}{*}{1} & \multirow[t]{2}{*}{2} & \multirow[t]{2}{*}{3} & \multirow[t]{2}{*}{4} & \multirow[t]{2}{*}{ 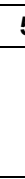 } \\
\hline \multirow{3}{*}{$\begin{array}{l}\text { Green process } \\
\text { innovation }\end{array}$} & $\begin{array}{l}\text { Low energy consumption, such } \\
\text { as water, electricity, gas and } \\
\text { gasoline, during production / } \\
\text { use / disposal. }\end{array}$ & & & & & \\
\hline & $\begin{array}{l}\text { Recycle, reuse and } \\
\text { remanufacture material. }\end{array}$ & & & & & \\
\hline & $\begin{array}{l}\text { Use cleaner technology to } \\
\text { save and prevent pollution } \\
\text { (such as energy, water and } \\
\text { waste). }\end{array}$ & & & & & \\
\hline \multirow[t]{2}{*}{$\begin{array}{l}\text { Green management } \\
\text { innovation }\end{array}$} & $\begin{array}{l}\text { Redefine operational and } \\
\text { production processes to } \\
\text { ensure internal efficiency, } \\
\text { which can help to } \\
\text { implement supply chain } \\
\text { management. }\end{array}$ & & & & & \\
\hline & $\begin{array}{l}\text { Redesign and improve the } \\
\text { product or service to obtain } \\
\text { new environmental criteria } \\
\text { or guidelines. }\end{array}$ & & & & & \\
\hline \multirow{3}{*}{$\begin{array}{l}\text { Environmental } \\
\text { performance }\end{array}$} & $\begin{array}{l}\text { Reduction of hazardous } \\
\text { waste, emission, and so } \\
\text { on. }\end{array}$ & & & & & \\
\hline & $\begin{array}{c}\text { Less water, electricity, } \\
\text { gas and gasoline } \\
\text { consumption. }\end{array}$ & & & & & \\
\hline & $\begin{array}{l}\text { Improvement of } \\
\text { environmental } \\
\text { compliance. }\end{array}$ & & & & & \\
\hline \multirow{4}{*}{$\begin{array}{l}\text { Competitive } \\
\text { advantage }\end{array}$} & Customer response. & & & & & \\
\hline & $\begin{array}{l}\text { Product design and } \\
\text { innovation. }\end{array}$ & & & & & \\
\hline & $\begin{array}{l}\text { Quality of product and } \\
\text { service. }\end{array}$ & & & & & \\
\hline & Low production cost. & & & & & \\
\hline
\end{tabular}

Source: Elaborated based on Chiou et al. (2011).

The study concluded with some limitations; however, it suggests that the results demonstrated that the requirement for a greener supplier generates innovations in ecological products, ecological processes and ecological management. In addition, the study concluded that, by generating innovations in ecological products, ecological processes and ecological management, the company obtains a competitive advantage.

\subsection{Comparisons between research instruments}

Further development of the three green innovation instruments will have been presenting in this section. The analysis is carried out, based on two perspectives, conceptual and methodological.

The initial comparison will have been making, on a conceptual basis, in which we tried to discuss the definitions of green innovation of the presented scales, making it possible to verify the similarities and different points between the theoretical concepts used. 
Chart 4. Theoretical conceptions.

\begin{tabular}{|c|c|c|}
\hline \multicolumn{3}{|c|}{ Green Innovation Concept } \\
\hline Chen et al. (2006) & Chen (2008) & Chiou et al. (2011) \\
\hline $\begin{array}{l}\text { Green innovation is } \\
\text { innovation that is related to } \\
\text { products or processes, } \\
\text { including innovation in } \\
\text { technologies that are } \\
\text { involved in energy saving, } \\
\text { pollution prevention, waste } \\
\text { recycling, green product } \\
\text { projects or corporate } \\
\text { environmental management. }\end{array}$ & $\begin{array}{l}\text { Green innovation is } \\
\text { innovation that is related to } \\
\text { products or processes, } \\
\text { including innovation in } \\
\text { technologies that are } \\
\text { involved in energy saving, } \\
\text { pollution prevention, waste } \\
\text { recycling, green product } \\
\text { projects or corporate } \\
\text { environmental management } \\
\text { (Chen et al., 2006, p. 4). }\end{array}$ & $\begin{array}{l}\text { Green innovation is innovation } \\
\text { made up of green product } \\
\text { innovation, green process } \\
\text { innovation and green } \\
\text { management innovation. }\end{array}$ \\
\hline \multicolumn{3}{|c|}{ Constructs Used } \\
\hline Chen et al. (2006) & Chen (2008) & Chiou et al. (2011) \\
\hline $\begin{array}{c}\text { - Green Product Innovation } \\
\text { Performance. } \\
\end{array}$ & - Green Central Competence. & - Greener supplier. \\
\hline $\begin{array}{l}\text { - Performance of Green } \\
\text { Process Innovation. }\end{array}$ & $\begin{array}{l}\text { - Green Product Innovation } \\
\text { Performance. }\end{array}$ & - Green Product Innovation. \\
\hline \multirow[t]{4}{*}{$\begin{array}{l}\text { - Corporate Competitive } \\
\text { Advantage. } \\
\end{array}$} & $\begin{array}{l}\text { - Green Process Innovation } \\
\text { Performance. } \\
\end{array}$ & - Green Process Innovation. \\
\hline & - Green image. & $\begin{array}{c}\text { - Green Managerial } \\
\text { Innovation. }\end{array}$ \\
\hline & & - Environmental performance. \\
\hline & & - Competitive advantage. \\
\hline
\end{tabular}

Source: Prepared based on Chen et al. (2006); Chen (2008) and Chiou et al. (2011).

The concept of green innovation, in the studies analyzed (Chart 4), is the same in the first two studies. This concept had proposed by Chen et al. (2006) and used by Chen (2008), encompassing innovation in green product, innovation in green process and innovation in green technologies. The instrument developed by Chiou et al. (2011) covers the two types of innovation used by Chen et al. (2006) and Chen (2008), innovation in green product and innovation in green process; however, it adds managerial innovation green. When analyzing the concept proposed, initially by Chen et al. (2006), he mentions the innovation in technologies that has involved in energy saving, pollution prevention, waste recycling, green product projects or corporate environmental management.

When it comes to analyzing the theoretical constructs elaborated in the projects (Chart 4), it has noticed that the first two works remain very similar, with the addition of new constructs in the work of Chen (2008). The Green Product Innovation Performance constructs and the Green Process Innovation Performance are similar, however, between one work and the other, Corporate Competitive Advantage vary in the first, and the construction of the Green Central Competency construct and use of other jobs of the Green Image construct, in the second, which denotes an evolution towards adaptation to management theories. The project of Chiou et al. (2011) builds its constructs, based on the work of Chen et al. (2006) and Chen (2008), however, adding new analyzes, focused on the green supplier chain and performance still not explored in the works mentioned.

The next Chart 5 presents the methodological elements of the analyzed articles in a comparative perspective. The general objectives, the numbers of variables, the sizes of the samples, the origin of the data, the types of scale and the analysis techniques will be analyzing. 
Chart 5. Methodological elements.

\begin{tabular}{|c|c|c|}
\hline \multicolumn{3}{|c|}{ Objective } \\
\hline Chen et al. (2006) & Chen (2008) & Chiou et al. (2011) \\
\hline $\begin{array}{c}\text { Explore whether the } \\
\text { performance of green } \\
\text { innovation has had a } \\
\text { positive effect on } \\
\text { competitive advantage. }\end{array}$ & $\begin{array}{l}\text { Propose a new construct, } \\
\text { green core competence, to } \\
\text { explore its positive effects } \\
\text { on green innovation and } \\
\text { green company images. }\end{array}$ & $\begin{array}{l}\text { Analyze the relations between } \\
\text { greening the supply chain, green } \\
\text { innovation, environmental } \\
\text { performance and competitive } \\
\text { advantage. }\end{array}$ \\
\hline \multicolumn{3}{|c|}{ Number of Variables } \\
\hline Chen et al. (2006) & Chen (2008) & Chiou et al. (2011) \\
\hline 16 & 21 & 22 \\
\hline \multicolumn{3}{|c|}{ Sample Size } \\
\hline Chen et al. (2006) & Chen (2008) & Chiou et al. (2011) \\
\hline $\begin{array}{l}300 \text { companies in the } \\
\text { information and electronics } \\
\text { industry. }\end{array}$ & $\begin{array}{l}300 \text { companies in the } \\
\text { information and electronics } \\
\text { industry. }\end{array}$ & $\begin{array}{l}124 \text { companies from eight } \\
\text { industry sectors. }\end{array}$ \\
\hline \multicolumn{3}{|c|}{ Data Sources } \\
\hline Chen et al. (2006) & Chen (2008) & Chiou et al. (2011) \\
\hline Taiwan & Taiwan & Taiwan \\
\hline \multicolumn{3}{|c|}{ Scale } \\
\hline Chen et al. (2006) & Chen (2008) & Chiou et al. (2011) \\
\hline Likert (5 pontos) & Likert (7 pontos) & Likert (5 pontos) \\
\hline \multicolumn{3}{|c|}{ Techniques used for analysis } \\
\hline Chen et al. (2006) & Chen (2008) & Chiou et al. (2011) \\
\hline - Cronbach's Alpha & - Correlation analysis & - Confirmatory Factor Analysis \\
\hline - Linear Regression & - Simple Regression & - Structural Equation Modeling \\
\hline - ANOVA One-way & - Cronbach's Alpha & - Cronbach's Alpha \\
\hline \multirow[t]{3}{*}{ - Paired t test } & $\begin{array}{c}\text { - Exploratory Factor } \\
\text { Analysis }\end{array}$ & - Item-total correlation \\
\hline & & - Composite Reliability \\
\hline & & - Average Variance extracted \\
\hline
\end{tabular}

Source: Prepared based on Chen et al. (2006); Chen (2008) and Chiou et al. (2011).

Analyzing the objectives of the research carried out, the only one, which aimed to create a new construct, was the project of Chen (2008), "proposing a new construct, competence of the green nucleus" aiming to analyze the effects on green innovation and the green image. The others propose a relation between performance and competitive advantage.

Analyzing the research instruments, the number of variables is evident, since a very large range can generate consequences, in relation to the minimum sample size, for the use of confirmatory modeling, required for the validation of measurement scales, as can be seen in Hair et al. (2005). The number of variables is between 16 and 22, not representing a significant difference that would justify a very different degree of complexity between studies about the sample size.

Regarding the sample size, only the project by Chiou et al. (2011) obtained a small number of companies surveyed in the study, which is even justified by the author.

There are some limitations to this research. First, 124 questionnaires were collected from 1569 organizations. Although this sample size is acceptable for this study, the response rate is still relatively low, which can affect the representativeness of this sample for all companies (Chiou et al., 2011, p. 832). 
The other studies presented samples, around 300 participating companies, which, according to Nascimento (2015), allow a high range of possibilities, in terms of possible analysis techniques, for the treatment of the collected data.

Regardind to the origin of the data collected, among the analyzed articles, all are located in Taiwan. Which does not mean that it would be considered that there are studies only in these regions about green innovation and competitive advantage, but it may represent the possibility of that, as they were the first to develop constructs between the relations proposed here, be the most cited and used in the basis of the Web of Science.

When considering the type of questionnaire construction and the measurement employed, all works used Likert-type scales, adopting five to seven points. In the case of ordinal scales, a variable falls into this category, as it satisfies an order, but the distance between the categories cannot be quantified (Gujarati \& Porter, 2011).

Examining the analysis techniques used, all studies make use of a confirmatory model, then validating the study, by employing regressions or modeling structural equations.

However, each study has its peculiarities, such as that involving the instruments, but all converge to quantitative procedures for measuring green innovation, through surveys of the type Inquiry, following hypothetical-deductive research guidelines (Popper, 2007; Nascimento, 2015). These guidelines show the ontological, epistemological and paradigmatic positions of the research analyzed here, adopting positivist and functionalist aspects of reality, covering the phenomenon as observable and susceptible to measurement (Kuhn, 2011; Morgan, 2005; Nascimento, 2015).

\subsection{Relations between research instruments}

Through the exposure and analysis of the research instruments, presented here, it was possible to apprehend the differences between the studies, from the characteristics that have related to the objectives of the project and that involve each article considered. How to relate Performance of Green Innovation and the Advantage Competitive (Chen et al., 2006), proposing a new construct, Central Green Competence (Chen, 2008) and relating the Greening of the supply chain, Green Innovation, Environmental Performance and Competitive Advantage (Chiou et al., 2011).

Analyzing the three research instruments, Chen (2008) stands out, as it is a measure of Green Innovation, at an organizational level that covers the previous work of Chen et al. (2006), improving it, in addition to being used as a reference for the construction of Chiou et al. (2011). In the construction of this instrument, the authors had concerned to relate the theme Green Innovation with themes such as Central Competence and Image, which allow evaluating under a Competitive Advantage perspective.

When the study by Chen (2008) has analyzed, no sample limitations have been identifing, in addition to this fact, the results present analysis procedures that demonstrate the robustness of the research instrument, enabling replication in studies that seek to measure the capacity of companies to innovate, in order to meet environmental requirements.

Among the relevant elements, for the analysis of the application of this research instrument, the study sample stands out, since it has developed in companies in the information and electronics industry, among them, small and medium-sized enterpries. The sample size has considered large, and the confirmatory results of the analysis procedures used show the robustness of the instrument. These facts, together, make it possible for the instrument has been appling, in other sectorial contexts and in studies, which aim to measure Green Innovation and the relationship with Competitive Advantage. 
As regards the methodological point of view, the number of indicators used in the constructs of Chen's project (2008), allows them have been using structural models, even with a small number of companies, as it works with many windows in constructs indicate the need for larger samples, which also increases the complexity of data collection project. In addition to this fact, the study developed by Chen (2008) allows several statistical analyzes, which makes it possible to expand the understanding of the phenomenon in the context in which its application is necessary.

\section{Final Considerations}

This essay aimed to investigate the scales used to measure green innovation and its relations with sustainable competitive advantage, as there is a great need to improve instruments, which generate greater reliability, to establish the relationship analyzed here.

The theoretical review enabled us to identify that the dimensions of green innovation have related to a wide range of topics that relate to the field of administration. Within the scope of sustainable competitive advantage, such as performance, core competence, image, supply chain management, among others, that make it impossible to develop a scale that simultaneously aggregates all the elements that affect sustainable competitive advantage. This statement has been apprehending in the scales presented in this article.

Therefore, this study suggests that the instruments developed and analyzed are valid efforts and that advance the understanding of the phenomenon, even if they have some limitations. For studies that seek to analyze the relationship between green innovation and sustainable competitive advantage, the instrument developed by Chen (2008) is the one that deserves greater emphasis, as it encompasses other projects and serves as a basis for the work of Chiou et al. (2011).

As limitations of the project, the use of a single scientific basis has considered, not least because the Web of Science, despite having more than 12,000 journals, is not the only basis that could contribute to a better delimitation of the field of study in question; a second limitation is that the analysis performed was descriptive. As an indication of new studies, it is suggesting, in addition to expanding the scope of the literature review, the proposition of building new scales that assess the relations between green innovation and dynamic capabilities geared to environmental requirements. An evolution of Resource Based studies Theory, as well as the validation of these studies in Brazil and other sectors, such as those that, by their nature, are highly polluting, such as the extractive industry and the chemical industry.

The present study did not aim to generalize the results, regarding the theme, nor to cover its entire scientific throughput, however, through the Web of Science database; an attempt had made to trace a path to start the discussion on the elaboration scales that direct research towards green innovation and companies' competitive advantage.

\section{References}

Adner, R., \& Helfat, C. E. (2003). Corporate effects and dynamic managerial capabilities. Strategic Management Journal, 24(10), 1011-1025. http://dx.doi.org/10.1002/smj.331.

Arenhardt, D. L., Battistella, L. F., Franchi, T. S. (2012). A influência da inovação verde na busca de vantagem competitiva das empresas dos setores elétrico e eletrônico brasileiro. In XXXVI Encontro da ANPAD. Rio de Janeiro, RJ. 
Barbieri, J. C., de Vasconcelos, I. F. G., Andreassi, T., \& de Vasconcelos, F. C. (2010). Inovação e sustentabilidade: novos modelos e proposições. RAE-Revista de Administração de Empresas, 50(2), 146-154. http://dx.doi.org/10.1590/S0034-75902010000200002.

Barney, J. (1991). Firm resources and sustained competitive advantage. Journal of Management, 17(1), 99-120. http://dx.doi.org/10.1177/014920639101700108.

Barney, J., \& Hesterly, W. S. (2011). Administração Estratégica e Vantagem Competitiva. Sao Paulo: Pearson Prentice Hall.

Beise, M., \& Rennings, K. (2005). Lead markets and regulation: a framework for analyzing the international diffusion of environmental innovations. Ecological Economics, 52(1), 5-17. http://dx.doi.org/10.1016/j.ecolecon.2004.06.007.

Bittar, M., Silva, M. R., \& Hayashi, M. C. P. I. (2011). Produção científica em dois periódicos da área de educação. Avaliação: Revista da Avaliação da Educação Superior, 16(3), 655-674. http://dx.doi.org/10.1590/S1414-40772011000300009.

Chen, Y. S. (2008). The driver of green innovation and green image-green core competence. Journal of Business Ethics, 81(3), 531-543. http://dx.doi.org/10.1007/s10551-007-9522-1.

Chen, Y. S., Lai, S. B., \& Wen, C. T. (2006). The influence of green innovation performance on corporate advantage in Taiwan. Journal of Business Ethics, 67(4), 331-339. http://dx.doi.org/10.1007/s10551-006-9025-5.

Chiou, T. Y., Chan, H. K., Lettice, F., \& Chung, S. H. (2011). The influence of greening the suppliers and green innovation on environmental performance and competitive advantage in Taiwan. Transportation Research Part E, Logistics and Transportation Review, 47(6), 822836. http://dx.doi.org/10.1016/j.tre.2011.05.016.

Conto, S. M., Antunes, J. A. V. Jr, \& Vaccaro, G. L. R. (2016). A inovação como fator de vantagem competitiva: estudo de uma cooperativa produtora de suco e vinho orgânicos. Gestão \& Produção, 23(2), 397-407. http://dx.doi.org/10.1590/0104-530x1677-14.

Coyne, K. P. (1986). Sustainable competitive advantage: what it is, what it isn't. Business Horizons, 29(1), 54-61. http://dx.doi.org/10.1016/0007-6813(86)90087-X.

Manual de Oslo (1997). Manual de Oslo: Proposta de diretrizes para coleta e interpretação de dados sobre inovação tecnológica. Paris: OCDE.

Manual de Oslo. (2005). Proposta de diretrizes para coleta e interpretação de dados sobre inovação tecnológica. Paris: OCDE.

Manual de Oslo (2018). Guidelines for collecting, reporting and using data on innovation. Paris: OCDE.

Gujarati, D. N., \& Porter, D. C. (2011). Econometria Básica. Porto Alegre: Bookman.

Hair, J. F., Anderson, R. E., Tatham, R. L., \& Black, W. C. (2005). Análise multivariada de dados. Porto Alegre: Bookman.

Hart, S. L. (1995). A natural-resource-based view of the firm. Academy of Management Review, 20(4), 986-1014. http://dx.doi.org/10.5465/amr.1995.9512280033.

Hitt, M. A., Ireland, R. D., \& Hoskisson, R. E. (2002). Administração estratégica. São Paulo: Pioneira Thomson Learning.

Ireland, R. D., Hoskisson, R. E., \& Hitt, M. A. (2014). Administração Estratégica. Tradução da 10a edição norte-americana. São Paulo: Cengage Learning.

Keller, K. L., \& Aaker, D. A. (1992). The effects of sequential introduction of brand extensions. JMR, Journal of Marketing Research, 29(1), 35-50. http://dx.doi.org/10.1177/002224379202900104.

Kemp, R., \& Arundel, A. (1998). Survey indicators for environmental innovation. IDEA paper. Oslo, Norway: STEP Group.

King, C. (2016). Web of Science: 1 Billion cited references and counting. Philadelphia, PA: Thomson Reuters. 
Klassen, R. D., \& Whybark, D. C. (1999). The impact of environmental technologies on manufacturing performance. Academy of Management Journal, 42(6), 599-615. http://dx.doi.org/10.5465/256982.

Kuhn, T. S. (2011). A estrutura das revoluções científicas. São Paulo: Perspectiva.

Lai, S. B., Wen, C. T., \& Chen, Y. S. (2003). The exploration of the relationship between the environmental pressure and the corporate competitive advantage. In Proceedings of the CSMOT Academic Conference. Hsin-Chu, Taiwan: National Chiao Tung University.

Lichtenthaler, U. (2009). Absorptive capacity, environmental turbulence, and the complementarity of organizational learning processes. Academy of Management Journal, 52(4), 822-846. http://dx.doi.org/10.5465/amj.2009.43670902.

Liu, W., Gu, M., Hu, G., Li, C., Liao, H., Tang, L., \& Shapira, P. (2014). Profile of developments in biomass-based bioenergy research: A 20-year perspective. Scientometrics, 99(2), 507-521. http://dx.doi.org/10.1007/s11192-013-1152-z.

Marchi, V. (2012). Environmental innovation and R\&D cooperation: empirical evidence from Spanish manufacturing firms. Research Policy, 41(3), 614-623. http://dx.doi.org/10.1016/j.respol.2011.10.002.

Miller, W. A., \& Morris, L. (1999). Fourth generation R\&D: Managing Knowledge, Technology, and Innovation. New York: John Wiley \& Sons.

Morgan, G. (2005). Paradigmas, metáforas e resolução de quebra-cabeças na teoria das organizações. RAE-Revista de Administração de Empresas, 45(1), 58-71.

Nascimento, T. C., Cherobim, A. P. M. S., \& Mendonça, A. T. B. B. (2013). Escalas de Capacidade Inovadora: Uma Revisão Sobre Proposições para Avaliação de Ambidestralidade em Organizações. In XXXVII Encontro da ANPAD. Rio de Janeiro: ANPAD.

Nascimento, T. C. (2015). Venture Capital como Instrumento de Financiamento à Inovação: Implicações do Aporte em Startups Brasileiras Capitalizadas pelo Fundo CRIATEC (Tese de doutorado). Universidade Federal do Paraná, Curitiba.

Pandza, K., \& Thorpe, R. (2009). Creative search and strategic sense-making: missing dimensions in the concept of dynamic capabilities. British Journal of Management, 20, S118-S131. http://dx.doi.org/10.1111/j.1467-8551.2008.00616.x.

Pinsky, V. C., Amaral Moretti, S. L., Kruglianskas, I., \& Plonski, G. A. (2015). Inovação sustentável: uma perspectiva comparada da literatura internacional e nacional. RAI Revista de Administração e Inovação, 12(3), 226-250. http://dx.doi.org/10.11606/rai.v12i3.101486.

Pinto, C. F., Serra, F. R., \& Ferreira, M. P. (2014). A bibliometric study on culture research in International Business. BAR - Brazilian Administration Review, 11(3), 340-363. http://dx.doi.org/10.1590/1807-7692bar2014309.

Popper, K. R. (2007). A lógica da pesquisa científica. São Paulo: Editora Cultrix.

Porter, M. (1985). Competitive Advantage. NY: Free Press.

Porter, M. E. (1996). What is Strategy? Harvard Business Review, 74(6), 61-78. PMid:10158475.

Porter, M., \& Van der Linde, C. (1995). Green and competitive: Ending the stalemate. Harvard Business Review, 73(5), 120-134.

Prado, J. W., Castro Alcântara, V., Melo Carvalho, F., Vieira, K. C., Machado, L. K. C., \& Tonelli, D. F. (2016). Multivariate analysis of credit risk and bankruptcy research data: a bibliometric study involving different knowledge fields (1968-2014). Scientometrics, 106(3), 1007-1029. http://dx.doi.org/10.1007/s11192-015-1829-6.

Prahalad, C. K., \& Hamel, G. (1990). The core competence of the corporation. Harvard Business Review, 68(3), 79-91.

Rao, P. (2002). Greening the supply chain: a new initiative in South East Asia. International Journal of Operations \& Production Management, 22(6), 632-655. http://dx.doi.org/10.1108/01443570210427668. 
Rao, P., \& Holt, D. (2005). Do green supply chains lead to competitiveness and economic performance? International Journal of Operations \& Production Management, 25(9), 898-916. http://dx.doi.org/10.1108/01443570510613956.

Schmidheiny, S., \& Timberlake, L. (1992). Changing course: A global business perspective on development and the environment. Cambridge: MIT Press.

Steger, U. (1993). The Green of the Board Room: how German companies are dealing with environmental issue. Environmental Strategies for Industry. Washington, DC: Island Press.

Teece, D. J. (2009). Dynamic capabilities and strategic management. New York: Oxford University Press.

Torres, L. B., Pagnussatt, T. B., \& Severo, E. A. (2017). A inovação como fonte para vantagem competitiva nas organizações: uma revisão sistemática da literatura. Revista GEINTEC Gestão, Inovação e Tecnologias, 7(4), 4028-4043. http://dx.doi.org/10.7198/geintec.v7.i4.1022.

Weiss, A. M., Anderson, E., \& Maclnnis, D. J. (1999). Reputation management as a motivation for sales structure decisions. Journal of Marketing, 63(4), 74-89. http://dx.doi.org/10.1177/002224299906300407.

Wernerfelt, B. (1984). A resource-based view of the firm. Strategic Management Journal, 5(2), 171180. http://dx.doi.org/10.1002/smj.4250050207. 